\title{
Hubungan Indeks Massa Tubuh dan Resistensi Insulin pada Anak Obes
}

Vivekenanda Pateda, Kristellina Sangirta Tirtamulia

Bagian Ilmu Kesehatan Anak Fakultas Kedokteran Universitas Sam Ratulangi Manado / BLU RSUP

Prof. Dr. R.D. Kandou, Manado

Latar belakang. Salah satu dampak obesitas pada anak adalah terjadinya diabetes tipe-2 yang didahului oleh terjadinya resistensi insulin. Belum diketahui apakah tingkat keparahan resistensi insulin semakin meningkat seiring dengan meningkatnya indeks massa tubuh (IMT) pada anak obes.

Tujuan. Mengetahui hubungan antara IMT dengan resistensi insulin pada anak obes.

Metode. Suatu penelitian observasional potong lintang yang dilaksanakan di Kecamatan Wenang, Kota Manado, Oktober 2009 sampai Januari 2010. Dilakukan pemeriksaan resistensi insulin dengan metode homeostasis model assessment of insulin resistance index (HOMA-IR) pada 54 anak obes berusia 10-14 tahun. Hubungan antara IMT dan HOMA-IR dianalisis dengan uji korelasi Pearson.

Hasil. Rerata IMT semua subjek 31,8 dan rerata HOMA-IR dari subjek 4,0. Uji korelasi Pearson memberikan hasil $\mathrm{p}=0,014 ; \mathrm{r}=0,298$.

Kesimpulan. Tidak terdapat hubungan antara indeks masa tubuh dengan resistensi insulin pada anak obes. Sari Pediatri 2011;12(5):315-8.

Kata kunci: indeks masa tubuh, resistensi insulin, anak obes

$\mathrm{P}$ erubahan gaya hidup beberapa tahun terakhir ini menyebabkan peningkatan angka kejadian obesitas pada anak. ${ }^{1,2}$ Di Indonesia, menurut data Riset Kesehatan Dasar (Riskesdas) tahun 2007, prevalensi berat badan lebih pada anak usia 6-14 tahun pada laki-laki adalah $9,5 \%$ dan perempuan adalah $6,4 \% .^{3}$

Obesitas merupakan keadaan patologis dengan

\section{Alamat korespondensi:}

Dr. Vivekenanda Pateda, Sp.A. Bagian Ilmu Kesehatan Anak, Fakultas Kedokteran Universitas Sam Ratulangi Manado / BLU RSUP Prof. Dr. R.D. Kandou. Jl. Raya Tanawangko Manado. Telp.: 0431-821652, Fax: 0431-859091, E-mail: vivepateda@yahoo.co.id terdapatnya penimbunan lemak yang berlebihan dari yang diperlukan untuk fungsi tubuh yang normal. ${ }^{2,4}$ Salah satu dampak negatif obesitas adalah resistensi insulin, yaitu ketidakmampuan insulin untuk menghasilkan fungsi biologik secara normal (menurunnya sensitivitas insulin), ditandai dengan peningkatan jumlah insulin puasa yang kemudian akan menyebabkan terjadinya peningkatan kadar glukosa darah. ${ }^{4,5}$ Selain diabetes tipe-2, resistensi insulin juga mendasari terjadinya sindrom metabolik dan polycystic ovarian syndrome (PCOS). ${ }^{6,7}$ Beberapa penelitian sebelumnya memperlihatkan bahwa $52 \%$ sampai $72 \%$ anak overweight dan obes mengalami resistensi insulin. ${ }^{8,9}$ 
Menurut Weiss $\mathrm{dkk}^{10}$ peningkatan obesitas berhubungan dengan tingginya resistensi insulin. Belum diketahui apakah tingkat keparahan resistensi insulin semakin meningkat seiring dengan meningkatnya indeks massa tubuh (IMT) pada anak obes. Untuk mengetahui apakah terdapat hubungan antara IMT dengan resistensi insulin pada anak obes, dilakukan penelitian pada anak obes di Kecamatan Wenang, Kota Manado.

\section{Metode}

Penelitian dilakukan dengan menggunakan metode analitik observasional dengan pendekatan potong lintang, di Kecamatan Wenang, Kota Manado, bulan Oktober 2009 sampai dengan Januari 2010. Di antara 44 sekolah dasar (SD) dan 17 sekolah menengah pertama (SMP) di kecamatan Wenang, dipilih secara random 20 sekolah dasar (SD) dan 10 sekolah menengah pertama (SMP). Pengambilan subjek dilakukan berdasarkan kriteria inklusi dan eksklusi. Kriteria inklusi adalah anak obes berusia 10-14 tahun (IMT lebih dari +3SD, referensi WHO 2007, untuk anak 5-19 tahun berdasarkan jenis kelamin). Kriteria eksklusi adalah tidak puasa saat pengambilan darah, berat lahir rendah, sindrom Cushing, keganasan serta sedang mendapat terapi kortikosteroid dan obat anti diabetik. Persetujuan orangtua diperoleh setelah diberikan penjelasan tentang tujuan, manfaat, dan prosedur penelitian.

Pada subjek yang memenuhi kriteria inklusi dan eksklusi, dilakukan pemeriksaan sensitivitas insulin menggunakan homeostasis model assessment of insulin resistance index (HOMA-IR), diperoleh dengan rumus, $99,102,103$

$$
\begin{aligned}
& \text { HOMA-IR }=\text { insulin }(\mu \mathrm{U} / \mathrm{mL}) \mathrm{x} \\
& \quad[\operatorname{glukosa}(\mathrm{mmol} / \mathrm{L}) / 22,5]
\end{aligned}
$$

Hasil penelitian dianalisis dengan uji korelasi Pearson dan analisis statistik dilakukan menggunakan program SPSS versi 17, dengan tingkat kemaknaan $<0,05$.

\section{Hasil}

Terdapat 55 orang anak obes berusia 10-14 tahun yang memenuhi kriteria inklusi dan eksklusi. Satu orang anak menolak pengambilan sampel darah, maka 54 orang anak diikutsertakan dalam penelitian. Karakteristik subjek tertera pada Tabel 1.

Tabel 1. Karakteristik subjek

\begin{tabular}{lc}
\hline Karakteristik & $\begin{array}{c}\text { Jumlah } \\
\mathrm{N}=54\end{array}$ \\
\hline Umur (tahun; rerata) & 12,2 \\
IMT $\left(\mathrm{kg} / \mathrm{m}^{2}\right.$, rerata) & 31,8 \\
Jenis kelamin & \\
$\quad$ - Laki-laki & 37 \\
- Perempuan & 17 \\
GDP (mmol/L, rerata) & 5,0 \\
Insulin puasa ( $\mu \mathrm{U} / \mathrm{mL}$, rerata) & 17,8 \\
HOMA-IR ( rerata) & 4,0 \\
\hline
\end{tabular}

IMT = indeks massa tubuh; DM-diabetes melitus; GDP=glukosa darah puasa; HOMA-IR= homeostasis model assessment of insulin resistance index

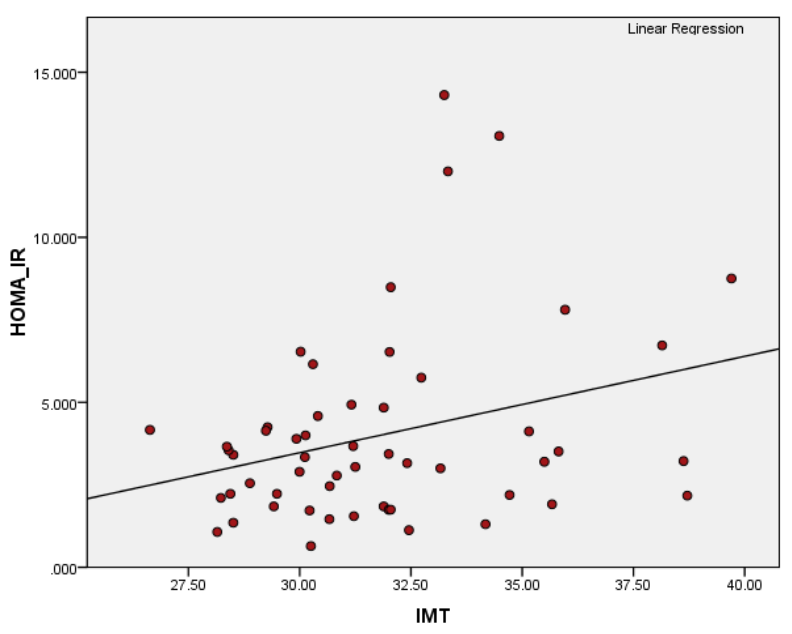

Gambar 1. Hubungan IMT dan HOMA-IR

Hasil pemeriksaan HOMA-IR semua subjek memberikan hasil dengan rentang 0,6 sampai 14,3, rerata HOMA-IR 4,0. Hubungan indeks massa tubuh dan HOMA-IR tertera pada Gambar 1. Uji korelasi Pearson dengan hasil $\mathrm{p}=0,014$ dengan $\mathrm{r}=0,298$.

\section{Pembahasan}

Wolff $\mathrm{dkk}^{11}$ dalam penelitiannya terhadap anak obes yang berusia 5-15 tahun mendapatkan bahwa obesitas lebih banyak terdapat pada anak laki-laki (60\%) daripada anak perempuan (40\%). Ikezaki $\mathrm{dkk}^{7}$ juga 
Vivekenanda Pateda dkk: Hubungan IMT dan resistensi insulin anak obes

mendapatkan hal yang serupa, di antara 105 anak obes yang diteliti, 61\% adalah laki-laki dan 39\% perempuan. Penelitian oleh Brufani $\mathrm{dkk}^{12}$ di sebuah klinik obesitas di Italia juga menemukan bahwa obesitas lebih banyak ditemukan pada anak laki-laki $(56,7 \%)$ daripada anak perempuan $(43,3 \%)$. Penemuan tersebut sesuai dengan subjek kami yang terdiri dari 37 (68,5\%) anak laki-laki dan 17 (31,5\%) anak perempuan. menurut Steinbeck, ${ }^{13}$ anak perempuan menunjukkan peningkatan lemak tubuh sejak usia 4 tahun sehingga mereka mempunyai lemak tubuh yang lebih banyak daripada anak laki-laki dan peningkatan ini melambat setelah memasuki masa remaja. Sebaliknya, anak laki-laki berkembang terus sampai usia dewasa muda.

Rerata nilai HOMA-IR 4,0, lebih tinggi daripada yang didapatkan oleh Ferreira $\mathrm{dkk}^{14}$ yang meneliti tentang sindrom metabolik pada anak di Brasil, yaitu $(3,1 \pm 1,8)$. Diperoleh pada anak obes nilai HOMA-IR lebih tinggi daripada anak overweight $(2,2 \pm 0,7)$ dan anak dengan berat badan normal $(1,2 \pm 0,5)$. Costa $\mathrm{dkk}^{15}$ dalam penelitiannya juga mendapatkan hasil yang serupa. Berdasarkan uji korelasi Pearson yang dilakukan, tidak terdapat hubungan antara IMT dan HOMA-IR. Penelitian sebelumnya mendapatkan hubungan bermakna antara obesitas dan resistensi insulin pada masa kanak-kanak, ${ }^{16,17}$ namun penelitian kami tidak mencari hubungan IMT dengan HOMA-IR pada anak obes.

Menurut Luukkaa dkk, ${ }^{18}$ IMT tidak dapat membedakan massa otot dari massa lemak, sehingga tidak dapat mengidentifikasi anak dengan peningkatan massa lemak. Penelitian selanjutnya oleh Ribeiro dkk ${ }^{19}$ menemukan bahwa bukan hanya massa lemak, tetapi distribusi lemak juga mempengaruhi risiko morbiditas dan mortalitas, terutama penyakit kardiovaskular. Hal ini dapat menerangkan mengapa pada penelitian kami tidak terdapat hubungan antara IMT dan HOMA-IR pada anak obes. Penelitian yang dilakukan oleh Kahn ${ }^{20}$ terhadap orang dewasa menemukan bahwa lipid accumulation product (LAP) lebih baik daripada IMT dalam mengidentifikasi resistensi insulin.

Penelitian kami mempunyai keterbatasan, antara lain besar sampel kurang dan penelitian ini tidak mencari korelasi antara IMT dan resistensi insulin pada anak overweight dan anak dengan berat badan normal. Dianjurkan untuk melakukan penelitian serupa dengan jumlah sampel yang lebih besar dan meliputi anak dari semua status gizi.

\section{Daftar pustaka}

1. Sahay BK, Sahay RK. Type 2 diabetes in the young. Int J Diab Dev Ctries 2003;23:51-4.

2. Soetjiningsih. Obesitas pada anak. Dalam: Ranuh IGNG, penyunting. Tumbuh kembang anak. Jakarta: EGC, 1995.h.183-90.

3. Kementriann Kesehatan Republik Indonesia. Riset Kesehatan Dasar (RISKESDAS) 2007. Jakarta: Depkes RI, 2008.

4. Steinberger J, Daniels SR. American Heart Association Atherosclerosis, Hypertension, and Obesity in the Young Committee (Council on Cardiovascular Disease in the Young), American Heart Association Diabetes Committee (Council on Nutrition, Physical Activity, and Metabolism). Obesity, insulin resistance, diabetes, and cardiovascular risk in children: an American Heart Association scientific statement from the atherosclerosis, hypertension, and obesity in the young committee (Council on Cardiovascular Disease in the Young) and the Diabetes Committee (Council on Nutrition, Physical Activity, and Metabolism). Circulation 2003;107:1448-53.

5. Arslanian SA. Type 2 diabetes mellitus in children: pathophysiology and risk factors. J Pediatr Endocrinol Metab 2000;13:1385-94.

6. Alemzadeh R, Wyatt DT. Diabetes mellitus in children. Dalam: Kliegman RM, Behrman RE, Jenson HB, Stanton BF, penyunting. Nelson textbook of pediatrics. Edisi ke-18. Philadelphia: Saunders; 2007.h.2404-31.

7. Ikezaki A, Miura N, Kikuoka N, Hye SK, Matsuoka $\mathrm{H}$, Ito K, dkk. Clinical characteristics of obese Japanese children with acanthosis nigricans. Clin Pediatr Endocrinol 2001;10:47-52.

8. Druet D, Dabbas M, Baltakse V, Payen C, Jouret B, Baud $\mathrm{C}$, dkk. Insulin resistance and the metabolic syndrome in obese French children. Clin Endocrinol 2006;64:672-8.

9. Lee JM, Okumura MJ, Davis MM, Herman WH, Gurney JG. Prevalence and determinants of insulin resistance among U.S. adolescents: a population-based study. Diabetes Care 2006;29:2427-32.

10. Weiss R, Dziura J, Burget TS, Tamborlane WV, Taksali SE, Yeckel CW, dkk. Obesity and the metabolic syndrome in children and adolescents. N Engl J Med 2004;350:2362-74.

11. Wolff C, Hoang S, Flannery D, Wermuth L. A preliminary study of diet, overweight, elevated blood pressure, and acanthosis nigricans among K-9 ${ }^{\text {th }}$ grade Native American students. Californian J Health Promotion 2006;4:77-87. 
12. Brufani C, Ciampalini P, Grossi A, Fiori R, Fintini D, Tozzi A, dkk. Glucose tolerance status in 510 children and adolescents attending an obesity clinic in Central Italy. Pediatr Diabetes 2010;11:47-54.

13. Steinbeck K. Childhood obesity: consequences and physical and psychosocial complications. Dalam: Kopelman PG, Caterson ID, Dietz WH, penyunting. Clinical obesity in adults and children. Massachusetts: Blackwell Publishing, 2005.h.231-48.

14. Ferreira AP, Oliveira CE, Franca NM. Metabolic syndrome and risk factors for cardiovascular disease in obese children: the relationship with insulin resistance (HOMA-IR). J Pediatr 2007;83:21-6.

15. Costa GB, Horta N, Resende ZF, Souza G, Barreto LMF, Correia LH. Body mass index has a good correlation with proatherosclerotic profile in children and adolescents. Arq Bras Cardiol 2009;93:261-7.

16. Goran M, Coronges K, Bergman R, Cruz M, Gower B.
Influence of family history of type 2 diabetes on insulin sensitivity in prepubertal children. J Clin Endocrinol Metab 2003;88:192-5.

17. Bacha F, Saad R, Gungor N, Janosky J, Arslanian S. Obesity, regional fat distribution, and syndrome in obese black versus white adolescents: race differential in diabetogenic and atherogenic risk factors. J Clin Endocrinol Metab 2003;88:2534-40.

18. Luukkaa V, Pesonen U, Hubtaniemi I, Lehtonen A, Tilvis $R$, Tuomilehto J, dkk. Inverse correlation between serum testosterone and leptin in men. J Clin Endocrinol Metab 1998;83:3243-6.

19. Ribeiro RQ, Lotufo PA, Lamounier JA, Oliveira RG, Soares JF, Botter DA. Additional cardiovascular risk factors associated with excess weight in children and adolescents: the Belo Horizonte heart study. Arq Bras Cardiol 2006;86:408-18.

20. Kahn HS. The lipid accumulation product is better than BMI for identifying diabetes. Diabetes Care 2006;29:151-3. 